\title{
Development of Storytelling Methods in Microteaching for Strengthening Prospective Teacher Competencies
}

\author{
Yusuf Abdul Hasan ${ }^{1, *}$ Anisa Dwi Makrufi ${ }^{2}$ Midawati $^{3}$
}

\author{
${ }^{1}$ Universitas Muhammadiyah Yogyakarta \\ ${ }^{2}$ Universitas Muhammadiyah Yogyakarta \\ ${ }^{3}$ Universitas Muhammadiyah Yogyakarta \\ *Email: yusufahasan@umy.ac.id
}

\begin{abstract}
Storytelling is a process in which every prospective teacher of Islamic Religious Education (as a teller) uses vocalization, narrative structure, and mental imagery to communicate with others who also use mental imagery and, in turn, communicate back through body language and facial expressions. The research objective is to find out and develop students' abilities in design planning and storytelling methods to strengthen their competence as prospective teachers. This research uses a Research and Development (R \& D) approach and has gone through a series of preliminary studies, ranging from theoretical studies and relevant research results as well as research location surveys. In this study, it was found that all respondents (student-teacher candidates participating in the Teaching Practice III course or Micro Teaching) in Islamic Education Department had difficulty using vocalizations, narrative structures and building mental images when they had to communicate a story that was assembled in the learning material of Islamic Religious Education (PAI). The development of the method of storytelling can be done in 7 steps, namely (1) the practice of compiling, studying, understanding and reciting self-compiled fables; (2) the practice of compiling fairy tale scripts into a core outline or fable outline; (3) the practice of controlling the length of the fable according to the duration available in a Micro Teaching program; (4) practice controlling vocabulary; (5) the practice of perfecting storytelling style; (6) practice of increasing the intensity of storytelling practice; and (7) practice forming relaxed habits before performing in class. The development of storytelling methods in a single unit with the learning package in a Learning Implementation Plan (RPP) is assumed to be useful for developing the competency of PAI teacher candidates as long as the application is following the ideal provisions of the implementation of microlearning, which includes a small number of practicing students and sufficient face-to-face time so every instructed student can appear to teach in class maximally.
\end{abstract}

\section{Keywords: Storytelling Method, Micro-teaching, Teacher Competence}

\section{INTRODUCTION}

The Islamic Religious Education Study Program, Faculty of Islamic Studies, Universitas Muhammadiyah Yogyakarta (hereinafter referred to as PAI Study Program) as the Educational Personnel Education Institute (LPTK) certainly has interests, responsibilities and a strategic position. As with other LPTKs, the PAI Study Program as a religious (Islamic) LPTK has the main task of providing education for prospective educational staff (teachers in the field of Islamic Religious Education) for all levels of education and expertise.

One of the basic courses, which are directly aimed at building the professional character of students as prospective teachers, is Micro Teaching (MT)[1]. In the PAI Study Program's Higher Education Curriculum, it is stated that MT is a compulsory subject with a weight of
4 credits. MT learning outcomes are (1) students master the concepts, principles, and application of various learning methods, especially those oriented towards life skills; (2) able to have the ability to manage Islamic Education learning independently; and (3) students are able to independently show a responsible attitude towards work in their field of expertise[2].

MT itself is an educational and training approach and technique for student-teacher candidates that can help them master skills such as teaching concepts from eye content certain lessons or courses and practice using specific teaching skills, all of which are limited in a short time in a mini-class whose participants are limited in number. Teaching exercises both offline and online via video recordings[3]. In this way, students practice learning in front of their peers (peer group teaching), then observed, measured and controlled in repeated cycles until they achieve measurable mastery of skills[4]. 
Even though learning is a complex process, and through MT, this complexity can be analyzed through simple learning activities carried out by MT students participating in the learning process in the MT class. The primary purpose of this activity is to promote learning activities among students, such as how they should build their skills in questioning, explaining, illustrating with examples, writing on the blackboard, drawing characters etc., both verbally and non-verbally[5].

Therefore, this specific learning activity can be said to be an art training or learning activity that can be observed, defined, measured, proven and can be developed through teaching skills training. Therefore, learning through the MT program also consists of a number of interrelated teaching skills that occur at various learning stages. According to Allen and Ryan, as quoted by Zainal Asril, stated that there are 14 teaching skills that are the focus of education and training in the MT course program. The fourteen teaching skills are (1) stimulus variation, (2) set induction, (3) set closure, (4) silence and non-verbal cues, (5) reinforcement of student participation, (6) fluency in asking question, (7) probing question, (8) higher-order questions, (9) divergent question, (10) recognizing attending behavior, (11) illustrating and use example, (12) lecturing, (13) planed repetition, and (14) completeness of communication[6].

The question that then arises is what the relationship between MT, teaching skills with storytelling and storytelling skills?

Storytelling, according to the Big Indonesian Dictionary (KBBI), is "a story that doesn't really happen (especially about strange ancient events)." As for storytelling, it is "telling fairy tales"[7]. From the educational perspective, storytelling is an activity to tell a fairy tale for a specific purpose, which is usually closely related to the education of values, character, morality or morals. Thus storytelling has educational and imaginative value and therefore has the advantage of being one of the main media for character education[8].

There are several vital factors in storytelling activities, namely (1) storytellers, (2) people who listen to fairy tales, (3) ideas or ideas about stories or fairy tales, and (4) the process of delivery, storytelling or storytelling. Without setting aside other factors, the process of delivery, storytelling or storytelling is a skill that has a close relationship with teaching skills in learning activities. It is assumed that the process of delivering a fairy tale requires the ability to communicate effectively both verbally and nonverbally. In it, a storyteller is required to have expertise in the use of words, use of sentences, processing vocals and visual processing appropriately[9].

Specifically, this study aims (1) to develop storytelling skills among students participating in MT lectures, which includes developing students' imaginative abilities to identify and find tales that are relevant to Islamic Education learning, compile fairy tales in a storytelling guide script, tell fairy tales in a communication frame, effective learning, and (2) experimenting with the application of these storytelling skills to increase students' ability in mastering teaching skills.

The urgency of this research is seen in the following matters. First, the PAI Study Program needs to seek breakthroughs to creatively find various models of teaching skills development for students participating in MT lectures[10]. Second, storytelling skills with all the elements of ability in them can be used as an alternative to this model and are assumed to have a significant impact on improving the teaching skills of prospective teacher students. Third, along with the development of storytelling skills and student teaching skills through MT, it is assumed that the positive character of students as prospective teachers will also develop so that in due time - in the post-MT learning program when students have to take part in the practical school program - students are able to implement instructional tasks in real classrooms and schools.

\section{METHOD}

\subsection{Types and Research Flow}

This research is a Research and Development ( $\mathrm{R} \&$ D) which will produce research products in the form of storytelling learning methods. This research has gone through a series of preliminary studies, starting from theoretical studies and relevant research results as well as survey research locations. Furthermore, to obtain an overview of the series of research activities, it is described in the following table and flow chart [11]:

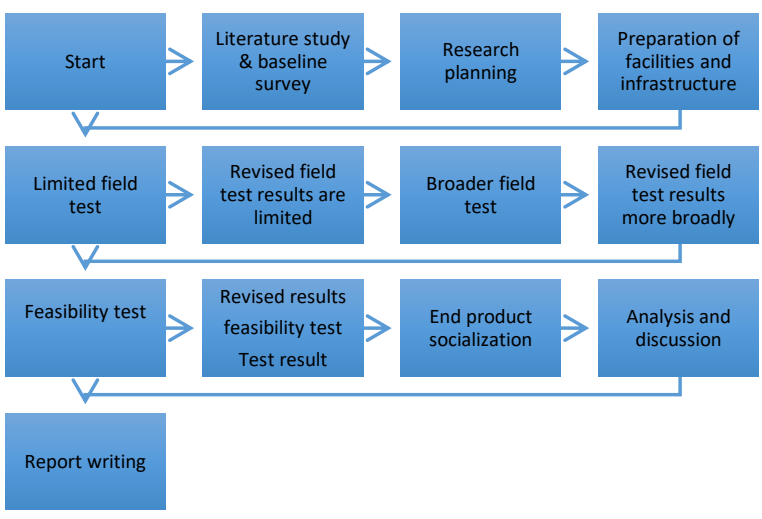

The selection of the types and lines of research above is based on the existence of similarity in flow with the approach used in micro teaching-learning. In general, micro teaching-learning is carried out in a cycle consisting of 6 stages. However, a cycle can be carried out in a varied and flexible manner according to needs. The six stages in the cycle can be seen in the following scheme[12]: 


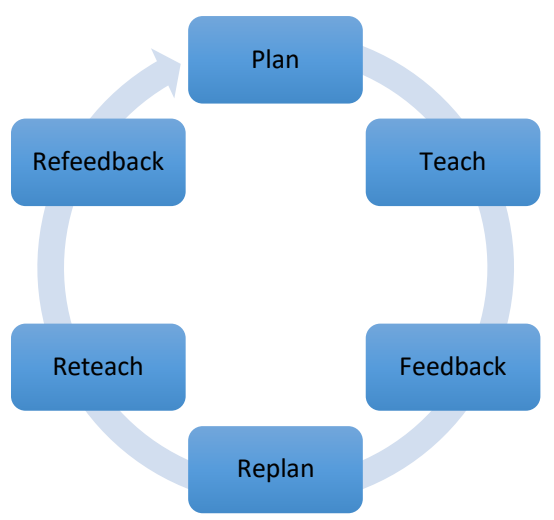

Chart 3. Stages of the Micro Teaching Learning Cycle

\subsection{Research Respondents}

The unit of analysis as a case study in this research is Semester VI students participating in the Teaching Practice III (Micro Teaching) course of the Islamic Religious Education Study Program (PAI) of the Islamic Religion Faculty (FAI) Muhammadiyah University of Yogyakarta (UMY). The number of respondents was 37 students who were in 2 classes, namely Class A totaling 12 students and Class E totaling 25 students.

\section{Research Sites}

This research was conducted at the Micro Teaching Laboratory of the Islamic Religious Education Study Program (PAI), Islamic Faculty (FAI), Muhammadiyah University of Yogyakarta (UMY). All tests are carried out in this laboratory because it has all the testing tools needed in research.

\section{Research Stages}

As in the research in the first year, the stages or steps carried out in this research are as follows:

a. Stage of literature study and field study. This stage is carried out to identify the problems faced and to formulate a work plan that will be carried out so that in this study, good results are obtained.

b. The research planning stage. At this stage, the research objectives are formulated, the estimated funding and research schedule as well as the formulation of the qualifications of the researchers and the form of participation in the research.

c. The design development stage. At this stage, the determination of the product design, the stage of the design test implementation, and the determination of the task description of the parties involved and the preparation of facilities and infrastructure needed during the research process.

d. The testing implementation stage. At this stage, testing is carried out with applicable standards in order to obtain accurate data. The test was carried out at the Laboratory of the PAI FAI UMY Study Program.

e. The data collection and analysis of test results. At this stage, the results of the tests are collected, then analyzed by content analysis, and conclusions are obtained.

\section{RESULT AND DISCUSSION}

\subsection{Characteristics of Respondents}

All research respondents were Semester 6 students participating in the Teaching Practice III (Micro Teaching) course. In the following semester, they will take part in the Teaching Practice IV program known as the Field Experience Program (PPL). This program is one of the mandatory activities that must be carried out by all PAI Study Program students, which include actual schooling practices - both curricular and non-curricular in particular schools to meet the requirements of the educational profession. Thus, students participating in the Teaching Practice III (Micro Teaching) lecture are deliberately prepared to have competence as practical teachers in schools, which are, in fact, in the PPL program the following semester.

All students participating in the Teaching Practice III (Micro Teaching) lecture are five classes. Respondents of this study were randomly selected, namely Class E and Class A, totaling 37 students. Class E consists of 25 students, and Class A has 12 students. Respondents in Class $\mathrm{E}$ are representatives of students who have average learning achievement. The respondents in Class A were students who were specially prepared to take part in the PPL program at Indonesian schools in Bangkok, Thailand (3 students), Indonesian schools in Johor Baharu, Malaysia (4 students), and Indonesian schools in Kuala Lumpur, Malaysia (5 students). ). Thus, the respondents in Class A are students who have abilities above average because they have taken a series of previous feasibility tests. In terms of the ability to tell storytelling and teach directly in class, both students in Class E and Class A all have no experience as teachers or storytellers. In the initial survey, it appears that both the respondents who are in Class E and Class A all do not have a good ability to choose and compose fairy tales and are weak in telling fairy tales.

\subsection{Briefing of Respondents}

The initial assessment carried out on the first day of the Teaching Practice III (Micro Teaching) showed that all respondents did not have teaching and storytelling experience. They also did not have theoretical insight into fairy tales or storytelling. This situation encouraged researchers to provide new insights to respondents about the theory and practice of storytelling for the benefit of Islamic Religious Education (PAI). At the first face-to- 
face, in addition to a study contract, theoretical insights about fairy tales and storytelling were also conveyed[9]:
a. The essence of fairy tales
b. Characteristics of fairy tales
c. Kinds of fairy tales
d. The benefits of storytelling
e. Selection of fairy tale themes
f. Storytelling techniques
g. Steps to storytelling
h. Media for storytelling, and
i. Requirements for storytellers.

In addition, outside of face-to-face hours in class, the research initiated the holding of a Storytelling Workshop attended by all respondents. The workshop with the theme "Developing Teacher Competence through Storytelling Activities," featured two storytelling practitioners from Yogyakarta, namely Ms. Rona Mentari and Mr. Abdul Wahab. Rona is a national storyteller and founder of the Mentari Fairy Tale House in Yogyakarta. Meanwhile, Abdul Wahab (Kak Awe) is an activist at Jawara Kampung Dongeng. Lots of storytelling experiences from both of them.

\subsection{Characteristics of Teaching Practice Course III (Micro Teaching)}

Micro Teaching is a training technique for teacher and student-teacher candidates that can help them to master skills and then form competencies as prospective teachers. In the Micro Teaching program, students are required to teach concepts from the content of the Ismuba subject (Al-Islam, Kemuhammadiyahan and Arabic), practice using specific teaching skills, all of which are limited in a short time in a mini-class where the number of participants is limited. In this way, students act as teachers who lead teaching and learning activities in front of their peers (peer group teaching), then observed, measured and controlled in repeated cycles until they achieve measurable mastery of skills.

In this study, Micro Teaching activities were carried out by paying attention to general procedures with the following steps:

Step one: specific skills that will be practiced are explained to the respondents of the Teaching Practice III (Micro Teaching), such as the objectives of the skills training, what are the components of that skill, and suitable examples. At this stage, a theory related to the storytelling method is given to the respondents to form their initial knowledge. Second step: respondents who are also students participating in Teaching Practice III (Micro Teaching) compile a fairy tale script, then teach, demonstrate or simulate storytelling skills in front of their peers, namely fellow student teacher candidates. The third step: the respondent designs a short lesson as a guide when he/she carries out teaching practices by including a story related to the teaching material. Fourth step: respondents teach learning materials to a small group of students and are supervised by supervisors (lecturers) and fellow respondents/students participating in Teaching Practice III (Micro Teaching). The fifth step: based on the results of observations, the supervisor provides feedback to the respondent. Supervisors (lecturers) provide reinforcement by providing examples of effective use of skills and criticizing students, especially for things they have not done satisfactorily. The sixth step: based on the feedback provided by the supervisor, the respondent re-plans (replans) the use of storytelling skills effectively in practice or the second cycle. Seventh step: the revised learning plan is taught again in the same Micro Teaching forum. The eighth step: the supervisor re-observes the re-teaching done by the respondent and provides feedback with clear and rational arguments. The ninth step: the "teach - feedback - reteach (teach again)" cycle, can be repeated until it reaches the desired ability.

\subsection{Storytelling in Learning Ismuba (Al-Islam, Kemuhammadiyahan and Arabic)}

In religious education (Islam), fairy tales are part of the cultivation of religious values. In the Koran, fairy tales (read: stories) are one of the methods used by Allah to explain the lives of the Prophets and Messengers and the teachings they carry, the condition of the former people who rejected the truth of revelation, praiseworthy characters and their human vices.

In this study, respondents as student-teacher candidates were required to compile a fairy tale or story related to Al-Islam in particular and included in the Lesson Program Plan (RPP). Respondents were guided to make use of the stories in the Qur'an, in the Sunnah of the Prophet, the stories of the Companions, the stories of the Wali, the tales of pious people, and it was possible to refer to the developing and legendary tales in Public.

\subsection{Development of the Storytelling Method}

As stated by Roney in Storytelling in the Classroom: Some Theoretical Thoughts (1996)[13], storytelling is a process in which a person (teller) uses vocalizations, narrative structures, and mental images to communicate with other people who also use mental imagery and, in turn, communicate back through body language and facial expressions.

In this study, all respondents had difficulty using vocalizations, narrative structures and building mental images when communicating a fairy tale that was assembled in Islamic Religious Education (PAI) learning materials. The steps that are then taken to improve this situation are to develop a 6-step strategy: 
First, the steps to compile, study, understand and read self-composed fairy tales. Compilation means that the respondent, with the assistance of the observer (lecturer/researcher), chooses a relevant story. Studying means to understand the characters involved in the fairy tale, the storyline, the main ideas contained in the fairy tale, the values that are relevant to the PAI material. Furthermore, respondents are interested in reading aloud, understanding and mastering the structure of the story, and trying to cultivate vocals and visuals.

Second, the core or outline of the fairy tale. This step is taken if the respondent has mastered storytelling in the first step. Memorizing word for word in the first step tends to divert the focus of the respondent's attention from the available time duration (20 minutes). Therefore, in this second step, the respondents gradually let go of their dependence on fairy tale texts.

Third, control the length of the fairy tale. In this step, respondents practice managing the available time to form effective and efficient learning. Fairy tales that are too long should be simplified. The duration of time available in the Micro Teaching program is 20 minutes. The first five minutes were used for set induction activities, and the last 5 minutes were designed for evaluation and closure sets. Ten minutes of the remaining time must be used to present the fairy tale mixed with the teaching material content.

Fourth, control vocabulary. In this step, the respondents practice using Indonesian that is good and correct. They must choose and use the right diction and vocabulary according to the characters that appear in the fairy tale. More or less, the observer (researcher/lecturer) provides a reiteration of the theory of standard Indonesian used for educational environments.

Fifth, perfecting style. In this step, the respondent explores vocalization (if vocals) and visualization (visual processing). In the vocal processing skills, the respondents made the necessary vocal changes according to the storyline, character characters, and story situations. In visual processing, respondents practice changing the appearance of facial expressions (facial expression), eye movements, head movements, empowerment of limb movements, movement (blocking, mastery of the classroom as a "stage" or story setting), as well as interacting with other students if necessary.

Sixth, increase the intensity of practicing storytelling. In this step, respondents are asked to practice outside the Micro Teaching class. The aim is to increase the amount of time spent practicing by making use of their free time outside the classroom, by using, for example, mirror media.

Seventh, forming a habit of relaxing before teaching. In this step, respondents are invited to develop a relaxed situation before and during the Micro Teaching activity. Doing light exercise, stretching and stretching muscles (stretching), practicing breathing are simple activities but have a good effect on improving the ability of respondents to tell the story while teaching in class.

\subsection{Significance of Storytelling Method Development with Teacher Candidates' Competencies}

As in the first year of research, every respondent participating in the Micro Teaching lecture was required to take part in teaching practice three times. In the first practice, respondents are free to choose teaching materials and methods applied in the learning process. Evaluation or assessment sheets for practical students are provided by the lecturer based on the agreement of the lecture participants. The assessment system is also carried out not only by lecturers but also by non-practical students. Aspects that are assessed in the first learning practice include skills in managing early learning activities, skills in explaining and asking questions, strategies and media used in the learning process, class management, time management, skills in managing final learning activities, appearance and neatness of the practitioner, Learning Implementation Plan ( RPP) which is compiled as well as practical discipline in terms of attendance.

The content or script of a fairy tale or story that was brought by each respondent as the practitioner was previously adjusted to the distribution of teaching materials agreed upon at the beginning of the lecture. There are seven subjects of Ismuba (Al-Islam, Kemuhammadiyahan and Arabic). Al-Islam consists of five subjects, namely: Aqidah Education, Worship Education and Muamalah, Moral Education, Date Education (Islamic History) and Qur'an Hadith Education. Each respondent received one theme from one Ismuba subject.

The second learning practice is a phase in which the respondent applies the fairy tale method in the Micro Teaching learning process. The use of costumes, media, content selection and voice characters have been agreed upon at the beginning of the lecture. In teaching practice using the first and second fairy tale methods, respondents seem not to have mastered the method of telling fairy tales in teaching practice in the Micro Teaching class. Neither Class E nor Class A shows any qualitative differences. The evaluation records indicate the following weaknesses:

a. Fairy tale content that is not relevant to the teaching material

b. The language used both in the fairy tale manuscripts in the lesson plans and in the practice of telling the story has not shown that it is not in accordance with the provisions of the Indonesian language properly and correctly.

c. Vocal processing feels flat, monotonous intonation no dynamic, and intermittent voice indicate that the respondent has not memorized the presented fairy tale. 
d. Weak visual exercises are shown by the use of facial expressions that are not optimal, gestures or body styles are still stiff, class mastery is not maximal (tends to be without movement or movement, and is still fixated on standing at one point).

The treatments performed to correct these weaknesses are as follows: All respondents are required to do homework in the form of improving all fairy tale texts both in the linguistic aspect and on the aspect of relevance. All respondents are required to include free media such as videos obtained from YouTube, image media that are contained in power points, assistive devices such as puppets, puppets, maps and so on.

In the third storytelling practice, respondents showed better results than the first and second stages of practice. The results of evaluations conducted by peers show the following notes:

a. The fairy tale manuscripts included in the lesson plans have shown relevance to the teaching material content at the level of $70 \%$ with good scores (75-80).

b. The fairy tale manuscripts included in the lesson plans have shown good and correct language use at the $80 \%$ level with good scores (70-75).

c. Vowel processing shows $80 \%$ of respondents with a value between 60-65 (enough).

d. Visuals show $75 \%$ of respondents with a score between 60-65 (sufficient).

Associated with the demands on the ability of prospective teachers who are prepared to take part in the Teaching Practice IV or Field Experience Program (PPL), the above achievements have a fairly good relevance in relation to the teacher competence of prospective teacher students. There are two domains of competence. First, pedagogic competence. Included in this area are fundamental skills in managing learning or teaching skills, which include (1) set introduction and closure: opening/closing lessons; (2) classroom management: managing classes; (3) reinforcement: providing reinforcement; (4) guiding small discussion: guiding a small discussion group; (5) questioning: giving questions; (6) explaining: explaining the lesson; and (7) variation stimulus: stimulate with a variation.

Second, social competence. Included in this area are the necessary skills of teachers in interaction and communication with students both inside and outside the classroom, both in curricular and non-curricular activities; teacher interaction and communication with peers, both at school and outside of school; teacher interactions with school leaders; teacher interaction with parents of students and society in general.

\subsection{Research Constraints and Limitations}

Not much different from research in the first year, in this study, the development of the storytelling method associated with the development of student competence as teacher candidates showed good results in terms of the relevance of fairy tale texts to the content of teaching material in Ismuba subjects, good results in terms of using good and correct Indonesian, and adequate results in terms of processing vocals and visual processing.

The interpretation of this value has not exceeded the minimum completeness criteria (KKM), the value of storytelling practice is 80.00 but has succeeded in exceeding the KKM for the overall assessment of Micro Teaching (assessment of lesson plans, respondent activeness in lecture programs, attendance value or the number of class attendance).

The main obstacle factors experienced by Micro Teaching lecture students in the application of the storytelling method are, among others, revolving around the use of standard language which they officially have to use in academic activities such as teaching, as well as obstacles in vocal processing and visual processing caused by previous things they do not know in their daily lives. The accumulation of all these obstacles is increasingly felt when they have to combine the skills to apply the storytelling method into a learning package that must be set out in the lesson plan.

Another obstacle at the same time shows that there are limitations to this study, namely related to the limited time available for face-to-face meetings in the Micro Teaching program. In the microlearning program, each practitioner should ideally practice teaching five times in different classes. This is not possible due to many factors, such as: lecture schedules that overlap between one course and another and the limited number of practice rooms (Micro Teaching classes).

In addition, the general provisions in the practice of Micro Teaching-learning, ideally each micro class, consists of a maximum of 10 practitioners. As reported above, Class E consists of 25 students, while Class A consists of 12 students. This has an impact on the availability of time that must be used for face-to-face meetings.

Another thing that is also an obstacle is that in the same semester, student practitioners (respondents to research) also take KKN courses (Real Work Lectures). This situation causes the student's concentration to be unable to be entirely concentrated on lecture activities for Teaching Practice III (Micro Teaching).

\section{CONCLUSION AND RECOMMENDATION}

\subsection{Conclusion}

Storytelling is a process in which every prospective Islamic Education teacher (as a teller) uses vocalizations, narrative structures, and mental images to communicate with other people who also use mental imagery and, in turn, communicate again through body language and 
facial expressions. In learning Al-Islam which consists of Aqidah Education, Worship and Muamalah Education, Moral Education, Date Education (Islamic History), and Hadith Qur`an Education, there are reference sources that are very rich in fairy tales and stories such as the Holy Bible. -Qur'an, Sunnah of Rasulullah saw, the story of the Companions, the story of the pious people, the tales of the Saints and Sunan, etc.

This paper discusses "Development of Storytelling Methods in Micro Teaching Learning to Strengthen Competence of Prospective Teacher Students". The research objective was to identify and develop students' abilities in planning design and storytelling methods to strengthen their competence as prospective teachers. This research uses a Research and Development (R \& D) approach and has gone through a series of preliminary studies, ranging from theoretical studies and relevant research results to research location surveys.

In this study, it was found that all respondents (prospective teacher) students participating in the Micro Teaching Practice course program had difficulty using vocalizations, narrative structures, and building mental images when they had to communicate a fairy tale arranged in Islamic Religious Education learning materials. Development of storytelling methods can be done in seven steps, namely (1) the practice of compiling, studying, understanding, and reading self-composed fairy tales, (2) the practice of compiling a fairy tale script to produce a core outline or outline of the story; (3) practice of controlling the length of the story according to the duration available in a Micro Teaching program; (4) practice controlling vocabulary; (5) the practice of perfecting storytelling styles; (6) practice increasing the intensity of practicing storytelling; and (7) practice forming relaxing habits before appearing in class.

The use of media in storytelling activities is an added point for the storytelling process itself. The development of this method should be aligned with the learning package in a lesson plan. So, the development of student competency, especially in terms of storytelling, can be achieved optimally as long as its application follows the ideal conditions for implementing microlearning.

\subsection{Recommendation}

First, the development of the Micro Teaching program as a key part of the formation of the competence of PAI Study Program students as PAI teacher candidates should refer to the provisions of implementing the Micro Teaching program as it has been known so far. The consequence of this demand is that the PAI FAI UMY Study Program should redesign or redesign the microlearning program, including developing the physical capacity of the Micro Teaching Laboratory as well as improving the learning program in the Teaching Practice III (Micro Teaching) course. Second, the Micro Teaching-learning program should be implemented in a specific semester in which students are no longer busy with other subject activities. Third, considering that some of the students participating in the Learning Practice III (Micro Teaching) lecture program are prepared to carry out Practical Field Experiences (PPL) abroad, the PAI Study Program should carry out assessments such as providing knowledge and skills about local languages and cultures so that they can master storytelling. Students will have a sumptuous RPP Al-Islam treasures by including more varied tales so as to accelerate the achievement of pedagogical competence and social competence of student PAI teacher candidates. Fourth, the Micro Teaching of PAI needs to initiate the publication of various PAI learning modules and related to the theme of this research, including a collection of Islamic fairy tales and fairy tale material learning modules that have high relevance for Islamic Education learning and the development of competence of PAI Study Program students as prospective teachers.

\section{ACKNOWLEDGMENTS}

The authors present their sincere appreciation to LP3M Universitas Muhammadiyah Yogyakarta, which has supported research funding. We also thank all those who have helped and were involved in this research, our students and the administrators of the micro-teaching laboratory of PAI FAI UMY.

\section{REFERENCES}

[1] M. Syafi 'i, P. Pendidikan, A. Islam, F. A. Islam, and K. Kunci, "IMPLIKASI PEMBELAJARAN MIKRO DALAM PENGEMBANGAN KETERAMPILAN MENGAJAR DI MADRASAH (Analisis Perkembangan Keterampilan Dasar Mengajar Mahasiswa Diniyah dalam Real Teaching Paska Pembelajaran Mikro Periode 2012/2013)," RELIGI, no. 1, 2012.

[2] B. Kadir, "Effect of Micro Teaching Technique on Teacher Candidates' Beliefs Regarding Mathematics Teaching," J. Procedia - Soc. Behav. Sci., 2015.

[3] D. Shaw, “Accomplished Teaching: Using Video Recorded Micro-Teaching Discourse to Build Candidate Teaching Competencies," J. Interact. Learn. Res., vol. 28, no. 2, pp. 161180, 2017, [Online]. Available: https://www.learntechlib.org/p/174167/.

[4] "LEARNER-CENTERED MICRO TEACHING IN TEACHER EDUCATION," Int. J. Instr., 2010.

[5] Aslihan Saban and A. N. Coklar, "Pre-Service Teachers' Opinions About The MicroTeaching," Turkish Online J. Educ. Technol., 2013.

[6] Z. Asril, Micro Teaching Disertasi dengan Pedoman Pengalaman Lapangan. Jakarta: PT. Raja Grafindo Persada, 2016. 
[7] B. P. dan P. Bahasa, "KBBI Daring," Kementerian Pendidikan dan Kebudayaan Republik Indonesia, 2020.

https://kbbi.kemdikbud.go.id/.

[8] E. Caminotti and J. Gray, "The effectiveness of storytelling on adult learning," J. Work. Learn., 2012, doi: 10.1108/13665621211250333.

[9] H. A. Alismail, "Integrate Digital Storytelling in Education," J. Educ. Pract., 2015.

[10] A. R. Saavedra and V. D. Opfer, "Learning 21st-Century Skills Requires 21st-Century

Teaching," Phi Delta Kappan, vol. 94, no. 2, pp. 8-13, 2012, doi:

$10.1177 / 003172171209400203$.

[11] C. A. Un, A. Cuervo-Cazurra, and K. Asakawa, "R\&D collaborations and product innovation," J. Prod. Innov. Manag., vol. 27, no. 5, pp. 673689, 2010, doi: $10.1111 / \mathrm{j} .1540-$

5885.2010.00744.x.

[12] P. J. McLeod, Y. Steinert, J. Trudel, and R. Gottesman, "Seven Principles for Teaching Procedural and Technical Skills," Acad. Med., vol. 76 , no. 10, p. 1080, 2001, doi: 10.1097/00001888-200110000-00023.

[13] R. C. Roney, "Storytelling in the Classroom: Some Theoretical Thoughts.," Storytell. World, 1996. 